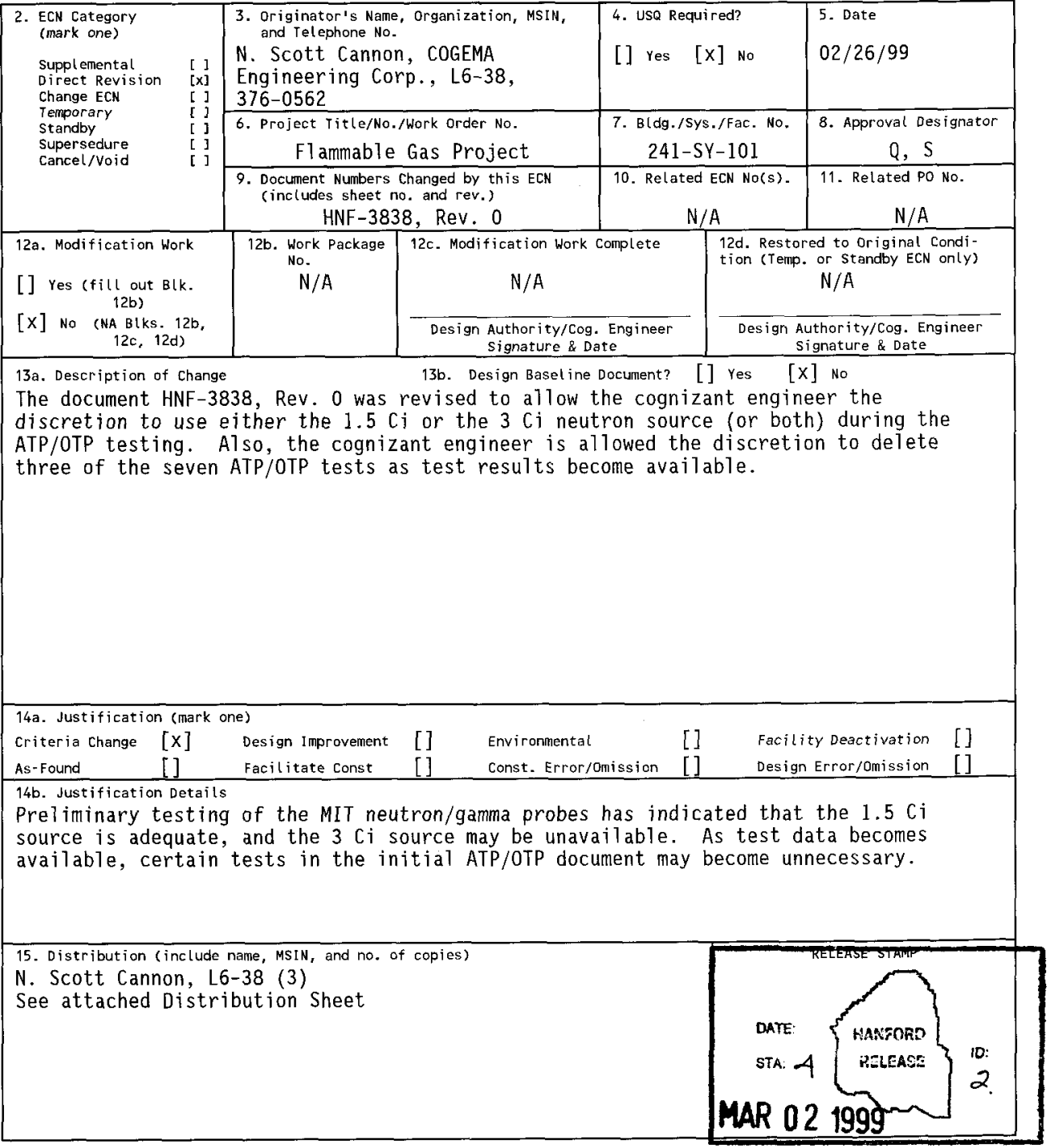

A-7900-013-2(05/96) GEF095 


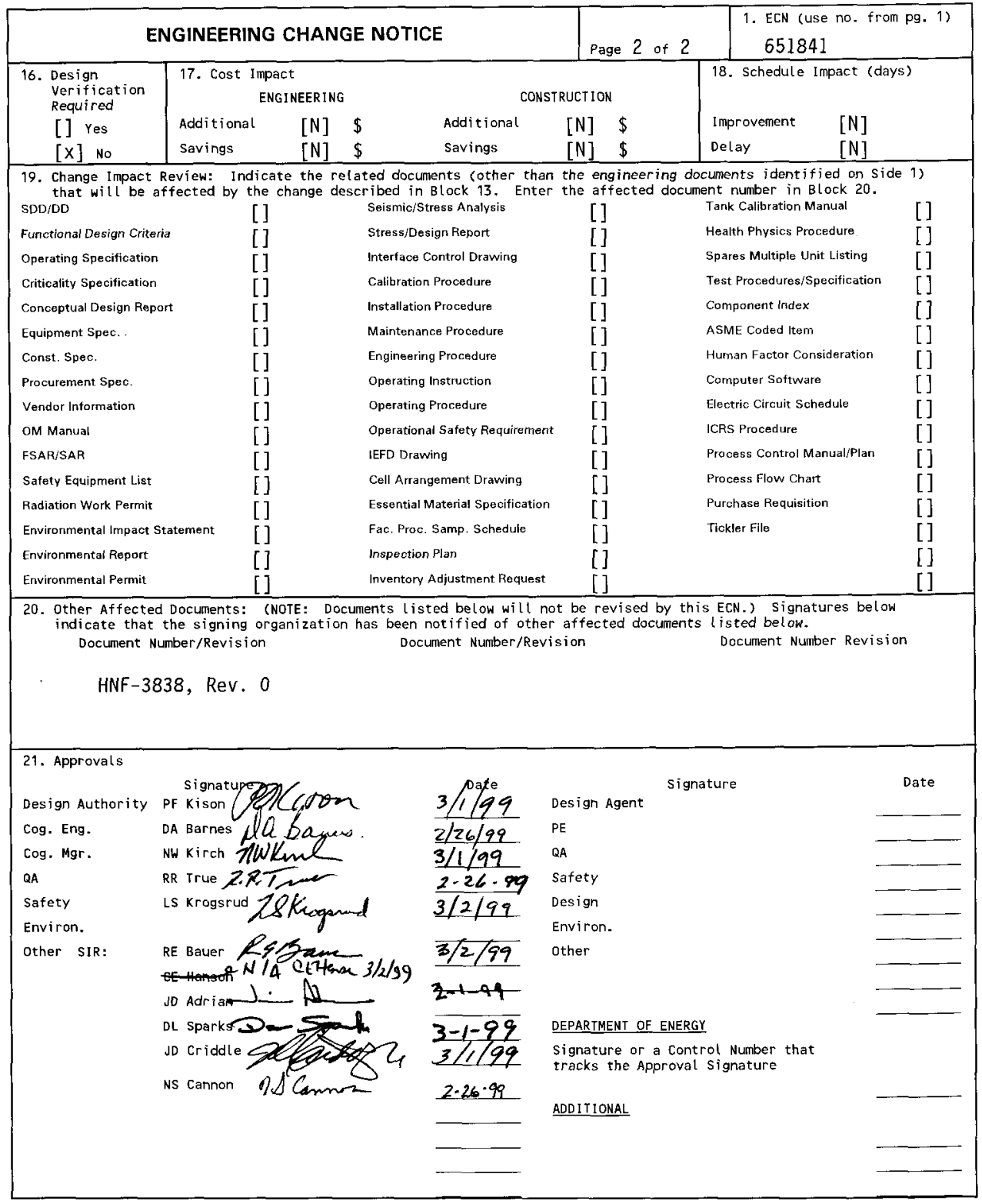




\section{Acceptance and Operational Test Procedure for Neutron and Gamma Probe Application to Tank 241-SY-101 MITs}

N. S. Cannon and J. G. Douglas

COGEMA Engineering Corporation, Rich1and, WA 99352

U.S. Department of Energy Contract DE-ACO6-96RL13200

\begin{tabular}{|c|c|c|c|}
\hline $\begin{array}{l}\text { DT/ECN: } \\
\text { rg Code: } \\
\text { \& R Code: }\end{array}$ & $\begin{array}{l}140125 / 651841 \\
08 E 00 \\
\text { EW3120074 }\end{array}$ & $\begin{array}{l}\text { UC: } 2070 \\
\text { Charge Code: } \\
\text { Total Pages: }\end{array}$ & 10 \\
\hline
\end{tabular}

Key Words: acceptance test, operational test, ATP/OTP, 241-SY-101, interstitial liquid leve? (ILL), neutron, gamma, probe, multifunction instrument tree (MIT), flammable gas, inventory, hazard, liquid observation well (LOW)

Abstract: This ATP/OTP provides procedures for testing to be performed to verify that newly procured neutron and gamma probes (reduced diameter design modifications) for operation in the Tank 241-SY-101 MITs are compatible with existing Low van instrumentation and hardware. A set of moisture data versus elevation will be obtained from the Tank 241-SY-101 MITs, and (optionally) from the Tank 241-AX-101 LOW as part of this testing program.

TRADEMARK DISCLAIMER. Reference herein to any specific commercial product, process, or service by trade name, trademark, manufacturer, or otherwise, does not necessarily constitute or imply its endorsement, recommendation, or favoring by the United States Government or any agency thereof or its contractors or subcontractors.

Printed in the United States of America. To obtain copies of this document, contact: Document Control Services, P.O. Box 950, Mailstop H6-08, Richland WA 99352, Phone (509) 372-2420; Fax (509) $376-4989$.
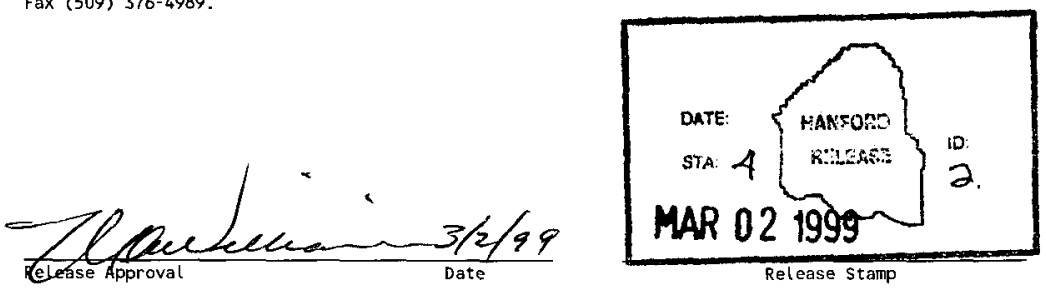

\section{Approved for Public Release}


(1) Document Number

HNF-3838

Page $r$

(2) Title

Acceptance \& Operational Test Procedure for Neutron \& Gamma Probe Application in Tank 241-SY

Change Control Record

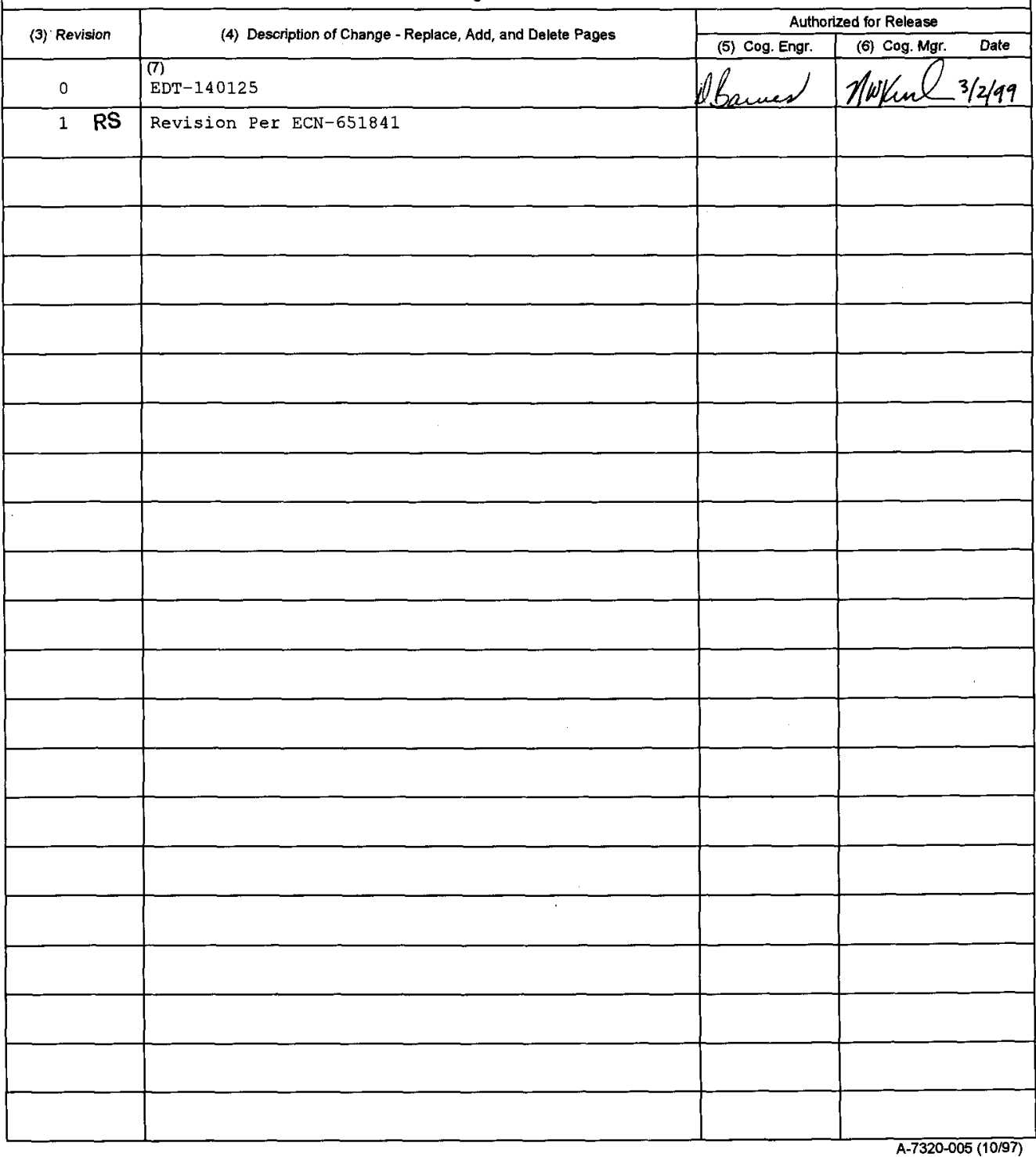




\section{ACCEPTANCE AND OPERATIONAL TEST PROCEDURE FOR NEUTRON AND GAMMA PROBE APPLICATION TO TANK 241-SY-101 MITs}

N. Scott Cannon

J. G. Douglas

COGEMA Engineering Corporation

March 1999 


\section{CONTENTS}

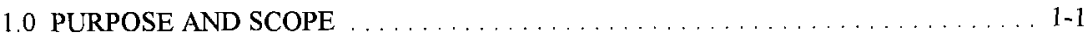

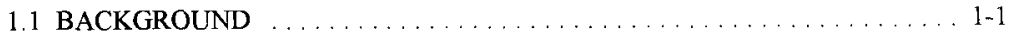

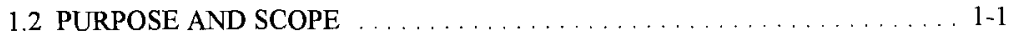

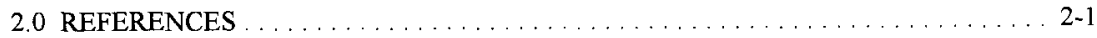

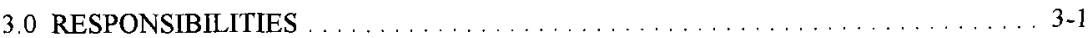

4.0 DESCRIPTION OF SYSTEM $\ldots \ldots \ldots \ldots \ldots \ldots \ldots \ldots \ldots \ldots \ldots \ldots \ldots \ldots . \ldots \ldots$

5.0 SAFETY AND QUALITY ASSURANCE $\ldots \ldots \ldots \ldots \ldots \ldots \ldots \ldots \ldots \ldots$

6.0 ACCEPTANCE/OPERATIONAL TEST PROCEDURES $\ldots \ldots \ldots \ldots \ldots \ldots \ldots$. . . 6 .

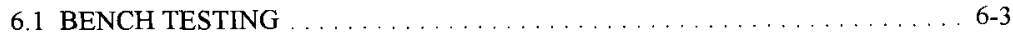

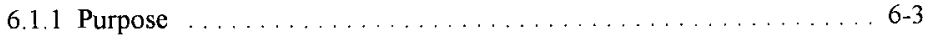

6.1 .2 Equipment Needed ....................... 6-3

6.1 .3 Bench Mechanical Test Procedure ... . . . . . . . . . . . . 6-4

6.1 .4 Bench Electrical Test Procedure . . . . . . . . . . . . . . . . . . 6-4

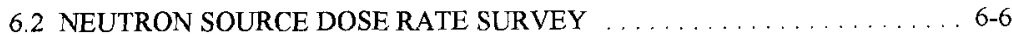

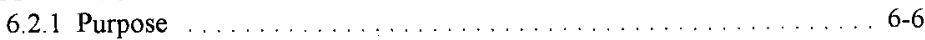

6.2 .2 Equipment Needed ....................... 6-6

6.2 .3 Test Location . . . . . . . . . . . . . . . . . . . . . . 6 6-6

6.24 Neutron Source Dose Rate Survey Procedure . . . . . . . . . . . . . . 6-6

6.3 DEPTH AND WEIGHT CALIBRATIONS $\ldots \ldots \ldots \ldots \ldots \ldots \ldots \ldots . \ldots \ldots$

6.3 .1 Purpose ........................... 6-8

6.3 .2 Equipment Needed . . . . . . . . . . . . . . . . . . 6-8

6.3 .3 Test Location . . . . . . . . . . . . . . . . . . . . . 6-8

6.3.4 Depth and Weight Calibration Procedure . . . . . . . . . . . 6-8

6.4 COUNT RATE DETERMINATION ... . . . . . . . . . . . 6-10

6.4 .1 Purpose ............................. 6-10

6.4 .2 Equipment Needed ......................... 6-10

6.4 .3 Test Location ... . . . . . . . . . . . . . . . . . . . 6-10

6.4.4 Neutron Probe Count Rate Determination Test Procedure . . . . . . . 6-11

6.4.5 Gamma Probe Count Rate Determination Test Procedure . . . . . . . . . 6-11

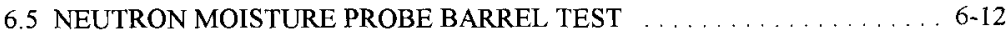

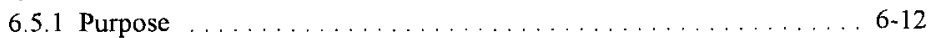

6.5 .2 Equipment Needed . . . . . . . . . . . . . . . . . 6-12

6.5 .3 Test Location . . . . . . . . . . . . . . . . . . . . . . . 6-13

6.5 .4 Wet Barrel Test Procedure . . . . . . . . . . . . . . . . . . 6 6-13

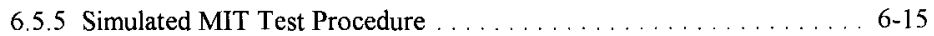

6.5.6 Simulated LOW Test Procedure ... . . . . . . . . . . . . . 6-16 
6.6 GAMMA AND NEUTRON PROBE TESTS IN TANK 241-AX-101 . . . . 6-18

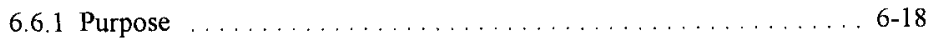

6.6 .2 Equipment Needed ........................ 6-18

6.6 .3 Test Location . . . . . . . . . . . . . . . . . . . . . . . . . 6-19

6.6.4 Tank 241-AX-101 Test Procedure ... . . . . . . . . . . . . . 6-19

6.7 GAMMA AND NEUTRON PROBE TESTS IN TANK 241-SY-101 . . . . 6-20

6.7 .1 Purpose ...........................6-20

6.7 .2 Equipment Needed . . . . . . . . . . . . . . . . . . . . . 6-20

6.7 .3 Test Location . . . . . . . . . . . . . . . . . . . . . . . . . . . 6-20

6.7.4 Tank 241-SY-101 Test Procedure . . . . . . . . . . . . 6-20

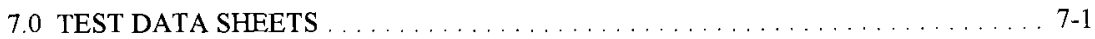

8.0 EXCEPTIONS TO OPERATIONS / ACCEPTANCE TEST SECTION $\ldots \ldots \ldots \ldots$. 1

9.0 TEST EXECUTION APPROVAL SHEET $\ldots \ldots \ldots \ldots \ldots \ldots \ldots \ldots \ldots \ldots \ldots$ 


\section{LIST OF TABLES}

1. 1. Functional Responsibilities for Neutron/Gamma Probe ATP/OTP . . . . . . . . . 3-1

6.1. Required Equipment for Mechanical and Electrical Bench Testing . . . . . . . . . . 6 6-3

6.2. Required Equipment for Neutron Source Dose Rate Survey . . . . . . . . . . . . . . . . 6-6

6.3. Required Equipment for Depth Test . . . . . . . . . . . . . . . . . . . 6-8

6.4. Required Equipment for Count Rate Determinations . . . . . . . . . . . . 6-10

6.5. Required Equipment for Neutron Moisture Probe Barrel Test . . . . . . . . . . . 6-12

6.6. Required Equipment for Gamma and Neutron Probe Tests in Tank 241-AX-101 . . . 6-18

6.7. Required Equipment for Gamma and Neutron Probe Tests in Tank 241-SY-101 . . . 6-20

\section{LIST OF DATA SHEETS}

DATA SHEET FOR BENCH TESTS SECTION $6.1 .3 \ldots \ldots \ldots \ldots \ldots \ldots \ldots \ldots \ldots$. $\ldots \ldots$

DATA SHEET FOR BENCH TESTS SECTION $6.1 .4 \ldots \ldots \ldots \ldots \ldots \ldots \ldots \ldots \ldots \ldots .7-2$

DATA SHEET FOR NEUTRON SOURCE DOSE RATE SURVEY PROCEDURE 6.2.4 . 7-3

DATA SHEET FOR DEPTH/WEIGHT TEST PROCEDURE $6.3 .4 \ldots \ldots \ldots \ldots \ldots \ldots .7 .4$

DATA SHEET FOR NEUTRON PROBE COUNT-RATE TEST PROCEDURE $6.4 .4 \ldots \ldots$. $7-5$

DATA SHEET FOR GAMMA PROBE COUNT-RATE TEST PROCEDURE $6.4 .5 \ldots \ldots 7-5$

DATA SHEET FOR BARREL TEST PROCEDURES $6.5 .4-6.5 .6 \ldots \ldots \ldots \ldots \ldots .7 .6$

\section{LIST OF ACRONYMS AND ABBREVIATIONS}

$\begin{array}{ll}\text { ATP } & \text { acceptance test procedure } \\ \text { CP } & \text { "cutie pie" beta/gamma dosimeter } \\ \text { DC } & \text { direct current } \\ \text { DVM } & \text { digital voltmeter } \\ \text { ETP } & \text { engineering task plan } \\ \text { ILL } & \text { interstitial liquid level } \\ \text { LOW } & \text { liquid observation well } \\ \text { MIT } & \text { multifunction instrument tree } \\ \text { OTP } & \text { operational test procedure } \\ \text { PVC } & \text { polyvinyl chloride }\end{array}$


HNF-3838 Rev. 1

\subsection{PURPOSE AND SCOPE}

\subsection{BACKGROUND}

Recent surface level measurements in Tank 241-SY-101 indicate a continuing increase in the crust surface level. To support investigation of this phenomenon, determination of the interstitial liquid level (ILL) in the tank is required. An Engineering Task Plan (ETP) has been developed (Cannon, 1998a) to use a neutron/gamma probe system in the multifunction instrument trees (MITs) of Tank 241-SY-101 to measure and track the ILL.

Liquid observation well (LOW) equipment already exists at the Hanford Site for measuring the ILL in a number of tanks. To use this equipment in the smaller-diameter MIT tubes, a neutron probe and a gamma probe with reduced diameters are required; the reduced neutron probe diameter requires an increase in the $\mathrm{Am} / \mathrm{Be}$ neutron source from 1.5 curies to approximately 3.0 curies. Probes with reduced diameters were purchased from Greenspan, Inc., Houston, Texas, under Lockheed Martin Hanford Corporation purchase order 1076. To use the reduced diameter probes in the MIT tubes, no changes in the LOW procedure or van instrumentation are expected.

\subsection{PURPOSE AND SCOPE}

The purpose of this acceptance/operation test procedure is to confirm that the reduced-diameter neutron moisture probe and gamma probe comply with the purchase specifications, are compatible with the existing LOW system, and are ready for operational field deployment. A test plan has been issued (Cannon, 1998b) and the combined acceptance and operational testing to be described in this document is required by that plan.

The primary tests to be performed under this test procedure are:

- Bench testing

- Dose rate checks with neutron probe source

- Depth and weight calibrations for the neutron and gamma probes

- Count rate determination to check the neutron and gamma probes

- Barrel test to calibrate neutron probe depth versus liquid interface level

- Test run with gamma and neutron probes in Tank 241-AX-101

- Test run with gamma and neutron probes in Tank 241-SY-101 
HNF-3838 Rev. 1

Once the above tests are completed, the data obtained will be reported and analyzed in a separate operational test report (OTR) document.

This ATP/OTP requires the use of the most recent revision of the tank farm plant operating procedure TO-040-333, Liquid Observation Well (LOW) Surveillance Van Startup and Operation Procedure (LMHC 1998). 


\subsection{REFERENCES}

Barnes, D. A., 1996, WHC-SD-WM-OTP-201, Rev. 0, Field Operational Test Procedure for the New Liquid Observation Well (LOW) Vans, Westinghouse Hanford Company, Richland, Washington.

Cannon, N. S., 1998a, Engineering Task Plan for Determining the Interstitial Liquid Level in Tank 241-SY-101 Utilizing a Neutron Probe in the Multifunction Instrument Tree HNF-3322, Rev. 0, COGEMA Engineering Corp. for Fluor Daniel Hanford, Inc., Richland, Washington.

Cannon, N. S., 1998b, Test Plan for Neutron Probe Application to Tank 241-SY-101 MITs, HNF-3595, Rev. 0, COGEMA Engineering Corp. for Fluor Daniel Hanford, Inc., Richland, Washington.

LMHC, 1998, Liquid Observation Well (LOW) Surveillance Van Startup and Operation Procedure, TO-040-333, Rev. A-4 (or latest revision), Lockheed Martin Hanford Corporation for Fluor Daniel Hanford, Inc., Richland, Washington.

LOW Survelillance Van Maintenance Manual, Rev. A-3, 1998, Greenspan, Inc., Houston, Texas. 


\subsection{RESPONSIBILITIES}

Table 1.1 outlines the functional responsibilities for this test procedure.

Table 1. 1. Functional Responsibilities for Neutron/Gamma Probe ATP/OTP

\begin{tabular}{|c|c|}
\hline Deroonnel & Responsibility. \\
\hline Cognizant Engineer & $\begin{array}{l}\text { - Approves ATP/OTP } \\
\text { - Witnesses tests (optional) } \\
\text { - Approves changes to tests as necessary } \\
\text { - Signs off upon completion of ATP/OTP }\end{array}$ \\
\hline Test Engineer & $\begin{array}{l}\text { NOTE: The Test Engineer and Cognizant Engineer may be the } \\
\text { same individual. } \\
\text { - Designated by Cognizant Engineer } \\
\text { - Witnesses tests } \\
\text { - Provides field guidance to operators as needed } \\
\text { - Recommends modifications to tests if required }\end{array}$ \\
\hline Operations Representative & $\begin{array}{l}\text { - Witnesses tests (optional) } \\
\text { - Signs off upon completion of ATP/OTP to certify equipment } \\
\text { is acceptable and ready for field use }\end{array}$ \\
\hline $\begin{array}{l}\text { Quality Assurance } \\
\text { Representative }\end{array}$ & $\begin{array}{l}\text { - Witnesses tests (optional) } \\
\text { - Writes test exceptions as necessary } \\
\text { - Assists with defining recovery actions as appropriate } \\
\text { - Signs off upon completion of ATP/OTP }\end{array}$ \\
\hline Safety Representative & Approves ATP/OTP \\
\hline LOW Van Operators & $\begin{array}{l}\text { A minimum of one lead operator should be present during } \\
\text { testing. } \\
\text { - Perform majority of physical operations } \\
\text { - Guided by Cognizant/Test Engineers as required } \\
\text { - Witnesses tests }\end{array}$ \\
\hline $\begin{array}{l}\text { Health Physics } \\
\text { Technologist }\end{array}$ & $\begin{array}{l}\text { - Provide dose rate survey of neutron probe source } \\
\text { - Provides dose rate surveys for calibration tests, as required }\end{array}$ \\
\hline
\end{tabular}




\subsection{DESCRIPTION OF SYSTEM}

The systems to be tested consist of:

- A neutron moisture probe, consisting of a source and detector, Neutron Probe \#9.

- A gamma probe, including the detector, Gamma Probe \#9.

These newly acquired, smaller diameter probes will also be referred to as the "MIT neutron probe" and the "MIT gamma probe," or the "MIT probes."

The MIT probes will be interfaced and tested with existing on-site LOW vans previously purchased from Greenspan, Inc. of Houston, Texas. A more complete description of the LOW vans is available in the Greenspan maintenance manual referenced in Section 2.0. 


\subsection{SAFETY AND QUALITY ASSURANCE}

This ATP/OTP is assigned the approval designators " $Q$ " and " $\mathrm{S}$."

All safety precautions noted in tank farm plant operating procedure TO-040-333 (LMHC 1998) will apply to those procedures in this ATP/OTP. The LOW van system has a safety designation of GS, and this designation will include the new MIT probes.

The new MIT neutron probe may require an increased strength neutron source (from $1.5 \mathrm{Ci}$ to approximately $3 \mathrm{Ci}$ ); this is the only difference between the MIT and LOW probes with respect to safety. However, the safety precautions of procedure TO-040-333 (latest revision) are expected to be adequate to provide protection for this increased source strength; if the $3 \mathrm{Ci}$ source is to be used in the field, testing will be performed herein (Section 6.2) to verify this assumption, or to identify additional safety steps required.

This ATP/OTP will be reviewed by Quality Assurance per HNF-PRO-233. Data quality objectives and calibration requirements are the same as those for the existing LOW van system (WHC-SD-WM-OTP-201, TO-040-333, LOW Maintenance Manual). 
HNF-3838 Rev. 1

\subsection{ACCEPTANCE/OPERATIONAL TEST PROCEDURES}


The LOW startup and operation procedure (TO-040-333, latest revision) will be used to perform specific test operations where applicable. The following procedures will identify where and when TO-040-333 steps will be followed. The individual procedures given for this ATP/OTP testing are summarized as follows:

- Bench Testing Procedure

- Neutron Source Dose Rate Survey

- Depth and Weight Calibration

- Count Rate Determination

- Neutron Probe Barrel Test

- Gamma and Neutron Probe Tests in the Tank 241-AX-101 LOW

- Gamma and Neutron Probe Tests in the Tank 241-SY-101 MITs

The order in which these individual procedures are performed during the ATP/OTP testing may be altered at the discretion of the cognizant engineer. Also, the Bench Testing, the Neutron Source Dose Rate Survey and the AX-101 LOW tests are optional, and may be deleted from the ATP/OTP and subsequent OTR at the discretion of the cognizant engineer.

For procedures that require a neutron source, either the 1.5 or the $3 \mathrm{Ci}$ source may be used, again at the cognizant engineer's discretion. The cognizant engineer may direct that individual tests be repeated, alternating the neutron source, so that test data is available for both sources. 


\subsection{BENCH TESTING}

Bench testing will be performed at the 272WA instrument shop. A set of mechanical tests and a set of electrical tests will be performed.

\subsubsection{Purpose}

The purpose of the bench testing is to verify the mechanical and electrical compatibility of the MIT probes with the LOW van.

\subsubsection{Equipment Needed}

Table 6.1. Required Equipment for Mechanical and Electrical Bench Testing

\begin{tabular}{|c|c|c|}
\hline (16.11) & Qurnotit & 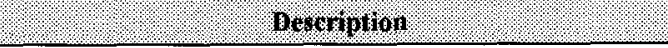 \\
\hline $\begin{array}{l}\text { LOW maintenance } \\
\text { manual }\end{array}$ & 1 & $\begin{array}{l}\text { LOW van maintenance manual, Revision A-3 (4/3/98) or } \\
\text { later. }\end{array}$ \\
\hline MIT neutron probe & 1 & $\begin{array}{l}\text { Greenspan, Inc., Neutron Probe } \# 9 \text {, with dummy source } \\
\text { holder and ballast attachment }\end{array}$ \\
\hline MIT gamma probe & 1 & Greenspan, Inc., Gamma Probe \#9, with ballast attachment \\
\hline Power supply & 1 & 30 volt $50 \mathrm{~mA}$ adjustable power supply with $\mathrm{mA}$ meter \\
\hline Resister & 1 & $100 \mathrm{ohm}$ resister ( $1 / 4$ watt) \\
\hline Capacitor & 1 & $33 \mathrm{pfd} 3000$ volt $(\mathrm{dc})$ capacitor \\
\hline Oscilloscope & 1 & $\begin{array}{l}50 \mathrm{MHZ} \text { oscilloscope with } \mathrm{X} 1 / \mathrm{X} 10 \text { probe } \\
\text { (Tektronix/equiv.) }\end{array}$ \\
\hline High Voltage Probe & 1 & $\begin{array}{l}\text { High Voltage Probe with DVM, } 1000 \mathrm{meg} \text {. ohm resister or } \\
\text { equivalent probe }\end{array}$ \\
\hline DVM & 1 & Fluke 77 DVM preferred \\
\hline Schematics & 1 & Electrical schematics for MIT neutron and gamma probes \\
\hline Neutron source & 1 & Either the 1.5 or $3 \mathrm{Ci}$ neutron source may be used \\
\hline Lab gamma source & 1 & Per LOW maintenance manual requirements \\
\hline Scale & 1 & Scale for weighing probes; $0.2 \mathrm{lbs}$ resolution or better \\
\hline Caliper & 1 & $\begin{array}{l}\text { Caliper or micrometer capable of } 0.001 \text { inch resolution } \\
\text { measurements between } 1.750 \text { and } 1.200 \text { inches }\end{array}$ \\
\hline Measuring Tape & 1 & $\begin{array}{l}\text { Measuring tape or ruler capable of measurements between } \\
20 \text { and } 28 \text { inches with } 1 / 16 \text { inch resolution or better }\end{array}$ \\
\hline
\end{tabular}




\subsubsection{Bench Mechanical Test Procedure}

Mechanical bench tests will be performed on both MIT probes to check probe outside diameter and length, and to measure the 'effective' weight of the probes. (The effective probe weight includes both the probe and its associated ballast.)

6.1.3.1 Measure the outside diameter (OD) of the both the MIT neutron probe and gamma probe; choose (arbitrarily) a zero degree rotation of a given probe, make a diameter measurement at each end, and at approximately the middle of the probe. Then rotate the probe 90 degrees and repeat the diameter measurements. Record all six results on the data sheets supplied in Section 7.0. Repeat for the other MIT probe. (The OD of both probes is expected at 1.85 inches.)

6.1.3.2 Measure the length for both MIT probes and record on the data sheet. (The length of the probes does not include the protective plug for the cable head threads.)

6.1.3.3 Weigh each MIT probe (with its ballast, if provided separately); the neutron probe should be weighed without the neutron source or source holder. (The source holder has previously been weighed at $0.8 \mathrm{lbs}$.) Record the weights on the data sheet. The weight of each probe (plus its ballast if separate) should be between 16.5 and 19.5 lbs.

\subsubsection{Bench Electrical Test Procedure}

The electrical bench tests of the MIT probes will be completed by performing the calibration and maintenance procedures provided in the LOW Surveillance Van Maintenance Manual (Greenspan, Inc.). The particular section of this manual to be employed is "Tool Calibration and Repair" (Section 8.0); any vendor procedure modifications specific to the MIT probes will be added to this section. These procedures will allow measurement of the probe current draw and determination that the pulse shapes for neutron and gamma counts are correct for the van electronics.

6.1.4.1 Perform the "Neutron Test and Calibration Procedure" from the LOW Maintenance Manual (Section 8) on the MIT neutron probe. Note that recording the current draw is not specifically required by this procedure. Once the electronics are set up per Figure 1 of the maintenance procedure and the power is turned on and warmed up (10 minutes), measure and record the current draw from the probe on the appropriate data sheet (see Section 7.0 of this document). Then continue with the rest of the maintenance procedure. Once the pulse shapes are verified (or adjusted) as correct, sign off the appropriate block on the data sheet.

6.1.2.2 Perform the "Gamma Test and Calibration Procedure" from the LOW Maintenance Manual (Section 8) on the MIT gamma probe. Note that recording the current draw is not specifically required by this procedure. Once the 
electronics are set up as Figure 1 of the maintenance procedure and the power is turned on and warmed up (10 minutes), measure and record the current draw from the gamma probe on the appropriate data sheet (see Section 7.0 of this document). Then continue with the rest of the maintenance procedure. Once the pulse shapes are verified (or adjusted) as correct, sign off the appropriate block on the data sheet.

Bench testing is now complete. 


\subsection{NEUTRON SOURCE DOSE RATE SURVEY}

\subsubsection{Purpose}

The purpose of this test is to determine the dose rate at various points in (and at) the LOW van with the three curie neutron source in the probe holder (both with the source attached to the probe, or unattached to the probe). A qualified health physics technologist (HPT) will perform the dose rate survey and record the survey results on the provided dose rate survey data sheet. Copies of the completed survey data sheet shall be sent to West Area Health Physics supervision, West Area Surveillance Operations managers, and Transportation Packaging.

\subsubsection{Equipment Needed}

Table 6.2 outlines the equipment needed for this test.

Table 6.2. Required Equipment for Neutron Source Dose Rate Survey

\begin{tabular}{|l|c|c|c|}
\hline MIT neutron probe & 1 & Greenspan, Inc., Neutron Probe \#9 \\
\hline $\begin{array}{l}\text { MIT neutron } \\
\text { source }\end{array}$ & 1 & $3-\mathrm{Ci}$ neutron probe source (in source holder) \\
\hline LOW van & 1 & equipped with probe holder (including MIT adapter) \\
\hline neutron detector & 1 & provided by Health Physics at time of survey \\
\hline CP & 1 & provided by Health Physics at time of survey \\
\hline
\end{tabular}

\subsubsection{Test Location}

These tests may be performed at the 272WA garage or another convenient location with appropriate radiation area postings.

\subsubsection{Neutron Source Dose Rate Survey Procedure}

NOTE: A qualified HPT will perform the survey according to any applicable Health Physics procedures at the points noted in this procedure.

6.2.4.1 Attach source to probe per procedure TO-040-333 (see Section 5.3). 
6.2.4.2 Insert probe into probe holder.

6.2.4.3 Record on data sheet the dose rate at (1) contact, (2) $30 \mathrm{~cm}$, and

(3) two meters from (a) right side of probe holder, (b) left side of probe holder, (c) top of probe holder, and (d) bottom of probe holder.

6.2.4.4 Uncouple source from probe per procedure TO-040-333.

6.2.4.5 Insert source into probe holder.

6.2.4.6 Record on data sheet the dose rate at (1) contact, (2) $30 \mathrm{~cm}$, and

(3) two meters from (a) right side of probe holder, (b) left side of probe holder, (c) top of probe holder, and (d) bottom of probe holder.

6.2.4.7 Record on data sheet the dose rate at (1) the driver's seat and (2) the passenger seat in the van. 


\subsection{DEPTH AND WEIGHT CALIBRATIONS}

\subsubsection{Purpose}

The depth of the depth test well at the 272WA garage is known to be $97.975 \mathrm{ft}$. It will be remeasured using the MIT gamma probe and an LOW van. The van software will then be adjusted (calibrated) as necessary to match the known well depth. Multiple depth calibrations will be run to check for accuracy and repeatability. Optionally, the neutron probe may also be used in the repeat tests. Only one LOW van will be used to perform these measurements.

Also, the digital "weight" of the probe system (probe, boom, etc.) will be measured from the van computer. This number must fall between 260 and 270 digits for the probe to function properly with the LOW van system. This number is related to the weight of the probe system, but is not the actual weight of the system components. It can be adjusted electronically, or by changing the weight of the probe.

\subsubsection{Equipment Needed}

Table 6.3 outlines the equipment needed for this test.

Table 6.3. Required Equipment for Depth Test

\begin{tabular}{|c|c|c|}
\hline (1.5. Item & ouranity & Bescription: \\
\hline MIT neutron probe & 1 & $\begin{array}{l}\text { Neutron Probe \#9, including the ballast and dummy source } \\
\text { holder }\end{array}$ \\
\hline MIT gamma probe & 1 & Gamma Probe \#9, including the ballast \\
\hline LOW van & 1 & Depth calibration software is already on the van computer \\
\hline Off-Set fixture & 1 & Also called the "spider" assembly \\
\hline
\end{tabular}

\subsubsection{Test Location}

These tests are to be performed at 272WA garage.

\subsubsection{Depth and Weight Calibration Procedure}

Set up the "spider" assembly at the 272WA Calibration Well and be sure that the well depth $(97.975 \mathrm{ft})$ is recorded in the van depth cal files. The following steps will be taken in compliance with procedure TO-040-333 (latest revision). 


\subsubsection{Gamma Probe Depth Calibration}

6.3.4.1.1 Prepare the LOW van for operation per Section 5 of the TO-040-333 procedure

6.3.4.1.2 Attach the MIT gamma probe (including the ballast above the cable head) to the LOW van cable head, in accordance with TO-040-333 (Section 5.11).

6.3.4.1.3 In compliance with Section 5.5 of TO-040-333, position (by hand) the probe tip over the test well.

6.3.4.1.4 With the gamma probe suspended in air, record the display value for the probe and boom assembly 'weight' on the data sheet (should be between 260 and 270 digits on the display; adjust if necessary per procedure) found in Section 7.0.

6.3.4.1.5 Perform the depth calibration (in compliance with Section 5.6 of TO-040-333 procedure), while performing the following steps:

- When the probe stops at the bottom of the cal well, record the raw depth and the pulses/inch from the computer screen on the data sheet for each depth pass.

- Adjust the 'known depth' in the script file to $97.975 \mathrm{ft}$

- Rerun the depth calibration twice more to check repeatability.

- Establish the depth cal constant (pulses/inch) for the van.

\subsubsection{Neutron Probe Depth Calibration}

6.3.4.2.1 Prepare the LOW van for operation per Section 5 of the TO-040-333 procedure.

6.3.4.2.2 Attach the MIT neutron probe to the LOW van cable head (per Section 5.11 of TO-040-333; but use dummy source), and also attach the separate ballast above cable head.

6.3.4.2.3 In compliance with Section 5.5 of TO-040-333, position (by hand) the probe tip over the test well

6.3.4.2.4 With the neutron probe suspended in air, record the display value for the probe and boom assembly weight on the data sheet (should be between 260 and 270 digits on the van display).

6.3.4.2.5 Optionally, repeat Step 6.3.4.1.5 with this neutron probe. 


\subsection{COUNT RATE DETERMINATION}

\subsubsection{Purpose}

The MIT neutron probe will be tested in the 272WA neutron calibration fixture to verify that the probe functions properly with the LOW van electronics and to establish the response of the probe in this fixture. After probe warmup, a series of count rate measurements will be made to establish an average that can be used in the future to verify correct probe operation prior to an MIT measurement run.

The MIT gamma probe will also be tested at $272 \mathrm{WA}$ in the gamma calibration fixture to verify that the probe functions properly with the LOW van electronics and to establish the response of the probe in this fixture. After probe warmup, a series of count rate measurements will be made to establish an average that can be used in the future to verify correct probe operation prior to an MIT measurement run.

\subsubsection{Equipment Needed}

Table 6.3 outlines the equipment needed for this test.

Table 6.4. Required Equipment for Count Rate Determinations

\begin{tabular}{|c|c|c|}
\hline tren & Quanity & Bercrption \\
\hline MTT neutron probe & 1 & Neutron Probe $\# 9$, including source $(1.5$ or $3 \mathrm{Ci})$ \\
\hline MIT gamma probe & 1 & Gamma Probe \#9 \\
\hline LOW van & 1 & Any of the LOW vans may be used \\
\hline Neutron Cal & 1 & Neutron calibration fixture at $272 \mathrm{WA}$ garage \\
\hline Gamma Cal & 1 & Gamma calibration fixture at 272 WA garage \\
\hline \#9_NEUT.PRB & 1 & Neutron calibration file for MIT neutron probe \\
\hline \#9_GAMMA.PRB & 1 & Gamma calibration file for MIT gamma probe \\
\hline
\end{tabular}

\subsubsection{Test Location}

These tests will be performed in the 272WA garage. 


\subsubsection{Neutron Probe Count Rate Determination Test Procedure}

NOTE: Before performing this procedure, prepare the LOW van for operation and attach the MIT neutron probe (Neutron Probe \#9) per TO-040-333 (Section 5). Perform the following operations in compliance with TO-040-333 Section 5.7 .

6.4.4.1 Insert probe into neutron calibration fixture.

6.4.4.2 Locate the calibration file (\#9_NEUT.PRB) on the computer menu, load the file, and perform 60 -second calibration runs until a run produces a count rate lower than the previous run (indicating that warm-up is complete).

6.4.4.3 Perform the next 60-second calibration run (data automatically recorded to computer).

6.4.4.4 Initial and date appropriate box on data sheet that the run was successfully completed.

6.4.4.5 Repeat steps 6.3.4.1 through 6.3.4.3 for a total of five runs.

\subsubsection{Gamma Probe Count Rate Determination Test Procedure}

NOTE: Before performing this procedure, attach the gamma probe (Gamma Probe \#9) to the LOW van and prepare the system for calibration per TO-040-333 (Section 5). Perform the following operations in compliance with TO-040-333 Section 5.7 .

6.4.5.1 Insert probe into gamma calibration fixture.

6.4.5.2 Locate the calibration file (\#9_GAMMA.PRB) on the computer menu, load file, and allow the system to warm up at least 10 minutes before performing a calibration run.

6.4.5.3 Perform a calibration run by counting the probe for 300 seconds in the calibration fixture. (Data are automatically saved to disk for future analysis.)

6.4.5.4 Initial and date appropriate box on data sheet that the run was successfully completed.

6.4.5.5 Repeat steps 6.3.5.1 through 6.3.5.3 for a total of five runs. 


\subsection{NEUTRON MOISTURE PROBE BARREL TEST}

\subsubsection{Purpose}

The purposes of this test are to (1) determine the exact location of the measurement point of the neutron probe and (2) determine the vertical resolution and maximum count-rate expected. Three tests will be performed on the probe: (1) the (essentially) bare probe in water, (2) the probe in a simulated MIT, and (3) the probe in a simulated LOW (optional test). In the first test, the probe will be inserted directly into a 55-gallon container of water. For this test, it is allowable for the probe to be encased in a thin plastic shroud to prevent water ingress into the probe electronics. In the second test, the probe will be inserted into a closed-end stainless steel pipe submerged in water to simulate a short section of an MIT. In the third test, the probe will be inserted into a closed-end polyvinyl chloride (PVC) pipe submerged in water to simulate an LOW. In each test, the count-rate signal will be recorded as the probe is withdrawn from the test apparatus. The computer on board the LOW van will control the count rate data collection and probe movement.

\subsubsection{Equipment Needed}

Table 6.5 outlines the equipment needed for this test.

Table 6.5. Required Equipment for Neutron Moisture Probe Barrel Test

\begin{tabular}{|c|c|c|}
\hline Iten & 919114ry & Bescription \\
\hline MTT neutron probe & 1 & Neutron Probe $\# 9$, including source $(1.5$ or $3 \mathrm{Ci})$ and ballast \\
\hline LOW van & 1 & Any of the LOW vans may be used \\
\hline barrel & 1 & plastic or steel 55 -gallon container, at least 42 inches tall \\
\hline wooden slat & 1 & $1 \times 4 \times 24$ inches \\
\hline shim stock & $\begin{array}{c}\text { as } \\
\text { required }\end{array}$ & cards, paper, wooden shims, or similar \\
\hline carpenter's level & 1 & minimum six-inch length \\
\hline water & $\begin{array}{l}40-50 \\
\text { gallons }\end{array}$ & \\
\hline kitchen detergent & $\begin{array}{l}\text { as } \\
\text { required }\end{array}$ & \\
\hline steel ruler or tape & 1 & minimum 36 -inch length, $1 / 32$-inch divisions \\
\hline
\end{tabular}


HNF-3838 Rev. 1

\begin{tabular}{|l|c|l|}
\hline $\begin{array}{l}\text { simulated PVC } \\
\text { LOW }\end{array}$ & 1 & \\
\hline $\begin{array}{l}\text { simulated stainless- } \\
\text { steel MIT }\end{array}$ & 1 & \\
\hline bungee cords & 2 & 12 -inch length \\
\hline software & 3 & Files WETBAR SCR, LOWBAR. SCR, and MITBAR. SCR \\
\hline plastic sleeve & 1 & $\begin{array}{l}\text { Plastic sleeve or shroud for 'sealing' neutron probe during } \\
\text { "bare" test }\end{array}$ \\
\hline
\end{tabular}

\subsubsection{Test Location}

These tests may be performed at the 272WA garage, or other suitable locations.

\subsubsection{Wet Barrel Test Procedure}

NOTE: Before performing this procedure, attach the MIT neutron probe to the LOW van and prepare the system for operation. Enclose the probe in the plastic sheath or shroud to prevent water penetration of the probe. Prepare the van for operation per TO-040-333 (Section 5)

NOTE: The same barrel set-up described in the wet barrel test procedure will also be used for the simulated MIT and optional LOW test procedures.

\subsubsection{Set-up}

6.5.4.1.1 Place 55-gallon barrel on a level location and place wooden $1 \times 4$ across the top. Level top of the $1 \times 4$ using shims as required.

6.5.4.1.2 Fill barrel to within approximately three inches of the top.

6.5.4.1.3 Add detergent to barrel and stir gently to avoid foaming (optional).

6.5.4.1.4 Measure distance from the water surface to top of $1 \times 4$ to within $1 / 32$ inch and record distance on data sheet. 
6.5.4.2.1 Using the pendant controls on the LOW van, position MIT neutron probe over the $1 \times 4$.

6.5.4.2.2 Start the probe control/data collection script WETBAR.SCR.

NOTE: $\quad$ During the next step, after the probe tip touches the $1 \times 4$, the probe should stop, pick up slightly to set the zero, then pick up an additional three inches.

6.5.4.2.3 Direct the probe tip onto the $1 \times 4$.

\subsubsection{Data Collection}

NOTE: During data collection, the computer will control probe movement and data collection. After the operator directs the probe into the water, the computer will lower the probe to a point near the bottom of the barrel, then withdraw the probe. When probe movement stops, the test is complete.

6.5.4.3.1 Direct the probe into the water.

6.5.4.3.2 Continue with the test script as prompted by the computer.

6.5.4.3.3 Download the data files to a floppy and enter onto a spreadsheet for plotting. The following four probe characteristics will be determined from the plotted data:

- Exact distance from tip of probe (zero point) to the effective measure point. (The effective measure point is at the $50 \%$ of the maximum count-rate position on the probe of the liquid interface.)

- Maximum count-rates in liquid environment.

- Interface resolution. (Determine the distance for which the count rate goes from $90 \%$ to $10 \%$ of the maximum value.)

- Signal-to-noise ratio. (Liquid counts/Air counts should be greater than 200:1 ratio.) Air counts may be a little high because of the proximity of the water. True air counts can be determined by manually raising the probe about three feet 
above the liquid level and counting for 60 seconds.

\subsubsection{Simulated MIT Test Procedure}

6.5 .5 .1 Set-up

NOTE: $\quad$ The simulated MIT test procedure assumes the same barrel set up as used for the wet barrel test.

6.5 5.1.1 Insert the closed end of the simulated MIT pipe into the water in the barrel. Fasten the pipe in place with bungee cords

6.5.5.1.2 Place $1 \times 4$ across the top of the plastic MIT. Level top of the $1 \times 4$ using shims as required.

6.5.5.1.3 Measure distance from the top of the $1 \mathrm{x} 4$ to the surface of the water to within 1/32 inch. Record distance on data sheet.

6.5.5.2 Zeroing

NOTE:

6.5 .5 .2 .3

NOTE:

\subsubsection{Data Collection}

NOTE:
The $1 \times 4$ is still in position on top of the MIT.

Using the pendant controls on the LOW van, position neutron probe over the opening of the MIT.

Start the probe control/data collection script MITBAR.SCR.

Direct the probe tip onto the $1 \times 4$.

Perform the next step after the computer has raised the probe off the $1 \times 4$.

Remove the $1 \times 4$ from the simulated MIT,

During data collection, the computer will control probe movement and data collection. After the operator directs the probe into the MIT, the computer will lower the probe to a point near the bottom of the barrel, then withdraw the probe. When probe movement stops, the test is complete. 
6.5.5.3.1 Direct the probe into the MIT.

6.5.5.3.2 Continue with the test script as prompted by the computer.

6.5.5.3.3 Repeat step 6.5.4.3.3 to determine the same four probe characteristics as were obtained during the wet barrel test.

\subsubsection{Simulated LOW Test Procedure}

Performance of this simulated LOW test is optional.

6.5.6.1 Set-up

NOTE: The simulated LOW test procedure assumes the same barrel set up as used for the wet barrel test. The plastic sleeve should be removed from the probe.

6.5.6.1.1 Insert the closed end of the simulated LOW pipe into the water in the barrel. Fasten the pipe in place with bungee cords.

6.5.6.1.2 Place $1 \times 4$ across the top of the plastic LOW. Level top of the $1 \times 4$ using shims as required.

6.5.6.1.3 Measure distance from the top of the $1 \times 4$ to the surface of the water to within $1 / 32$ inch. Record distance on data sheet.

6.5.6.2 Zeroing

NOTE: The $1 \times 4$ is still in position on top of the LOW.

6.5.6.2.1 Using the pendant controls on the LOW van, position neutron probe over the opening of the LOW.

6.5.6.2.2 Start the probe control/data collection script LOWBAR.SCR.

6.5.6.2.3 Direct the probe tip onto the $1 \times 4$.

NOTE: Perform the next step after the computer has raised the probe off the $1 \times 4$.

6.5.6.2.4 Remove the $1 \times 4$ from the simulated LOW. 
NOTE: During data collection, the computer will control probe movement and data collection. After the operator directs the probe into the simulated LOW, the computer will lower the probe to a point near the bottom of the pipe, then withdraw the probe. When probe movement stops, the test is complete.

6.5.6.3.1 Direct the probe into the LOW.

6.5.6.3.2 Continue with the test script as prompted by the computer.

6.5.6.3.4 Repeat step 6.5.4.3.3 to determine the same four probe characteristics as were obtained during the wet barrel test. 


\subsection{GAMMA AND NEUTRON PROBE TESTS IN TANK 241-AX-101}

\subsubsection{Purpose}

The new MIT probes and an LOW van will be used at the Tank 241-AX-101 LOW while utilizing the van offset fixture. (The offset fixture is not required at this LOW, but will be needed at the SY-101 MITs; thus it is used here to make the operations at both tanks comparable.) At least one run in this LOW will be performed with both the MIT probes. The MIT neutron probe will be run again in the LOW without the neutron source in order to quantify background gamma counts. The neutron probe count-rate determined without the neutron source installed shall be less than two percent of the count-rate determined with the neutron source installed.

Also, this MIT probe data will allow a comparison of results between MIT and LOW probes, utilizing LOW probe data obtained on prior occasions. The objective of this comparison is to show that (at least qualitatively) all major moisture features detected with the LOW probes can also be observed with the new MIT probes.

\subsubsection{Equipment Needed}

Table 6.6 outlines the equipment needed for this test.

Table 6.6. Required Equipment for Gamma and Neutron Probe Tests in Tank 241-AX-101

\begin{tabular}{|c|c|c|}
\hline Ktem & Qunutiv. & Dorgription \\
\hline MIT neutron probe & 1 & Neutron Probe \#9, including neutron source $(1.5$ or $3 \mathrm{Ci})$ \\
\hline MIT gamma probe & 1 & Gamma Probe \#9 \\
\hline LOW van & 1 & $\begin{array}{l}\text { Any LOW van fitted with the MIT probe holder adaptor, } \\
\text { including MIT probe software files. All van equipment } \\
\text { required to perform a normal field job, including morning } \\
\text { cals, spider mode surveys (both gamma and neutron), after } \\
\text { survey cals, and data downloading. }\end{array}$ \\
\hline Offset Fixture & 1 & Offset fixture (spider) assembly \\
\hline software & 1 & Script files for Tank AX-101 \\
\hline
\end{tabular}




\subsubsection{Test Location}

These tests will be performed at Tank 241-AX-101 LOW. In addition, the cognizant engineer may choose to repeat these tests at another tank LOW, selected at his discretion.

\subsubsection{Tank 241-AX-101 Test Procedure}

NOTE: This test is essentially a normal neutron/gamma probe run at the AX-101 LOW, with a few minor differences, which will be identified in the procedures called out below. All operations to prepare the MIT probes and the LOW van system for operation shall be performed in compliance with the most recent revision of TO-040-333 procedures (Section 5).

6.6.4.1 Perform LOW van log-on as per operating procedure (TO-040-333, Section 5).

6.6.4.2 Perform depth calibration per operating procedure.

6.6.4.3 Perform neutron calibration for MIT neutron probe per operating procedure.

6.6.4.4 Perform Gamma Calibration for MIT gamma probe per operating procedure.

6.6.4.5 The first scan record of the LOW using the MIT probes will be used as a reference scan for all subsequent surveys. Loading the reference survey on the $\mathrm{PC}$ will be done by the surveillance cognizant engineer, and will need to be done only once.

6.6.4.6 In the LOW, perform an MIT gamma probe scan, then an MIT neutron probe scan (with neutron source installed), and finally an MIT neutron probe scan (without the neutron source installed).

6.6.4.7 After the van has completed these scans, return to the 272WA garage.

6.6.4.8 Plug in modem line to computer data pigtail and download data (F6 function key on computer keyboard). 


\subsection{GAMMA AND NEUTRON PROBE TESTS IN TANK 241-SY-101}

\subsubsection{Purpose}

The purpose of this test is to demonstrate the operability of the MIT probes and LOW van at the Tank 24l-SY-101 MITs and to obtain the first neutron probe moisture data from this tank. The data will be analyzed to determine the value of this moisture data prior to establishing regular LOW van/MIT probe operations at SY-101

\subsubsection{Equipment Needed}

Table 6.7 outlines the equipment needed for this test.

Table 6.7. Required Equipment for Gamma and Neutron Probe Tests in Tank 241-SY-101

\begin{tabular}{|l|c|l|l|}
\hline MIT neutron probe & 1 & Neutron Probe \#9, including neutron source (1.5 or 3 Ci) \\
\hline MIT gamma probe & 1 & Gamma Probe \#9 \\
\hline LOW van & 1 & $\begin{array}{l}\text { LOW van with modified probe holder, including MIT probe } \\
\text { software files. All van equipment required to perform a } \\
\text { normal field job, including morning cals, spider mode } \\
\text { surveys (both gamma and neutron), after survey cals, and } \\
\text { data downloading. }\end{array}$ \\
\hline Offset Fixture & 1 & Offset fixture (spider) assembly \\
\hline Software & 1 & Script files for Tank 241-SY-101 installed on van computer \\
\hline
\end{tabular}

\subsubsection{Test Location}

These tests will be performed at Tank 241-SY-101 in both MITs.

\subsubsection{Tank 241-SY-101 Test Procedure}

NOTE: This test is essentially a normal neutron/gamma probe run at other LOWs, with a few minor differences, which will be identified in the procedures called out below. All operations to prepare the MIT probes and the LOW van system for operation shall be performed in compliance with the most recent revision of TO-040-333 procedures (Section 5). 
6.7.4.1 Perform LOW van log-on as per operating procedure (TO-040-333).

6.7.4.2 Perform depth calibration per operating procedure.

6.7.4.3 Perform neutron calibration for MIT neutron probe per operating procedure.

6.7.4.4 Perform gamma calibration for MIT gamma probe per operating procedure.

6.7.4.5 The first scan record of each MIT using the new MIT probes will be used as a reference scan for all subsequent surveys. Loading the reference survey on the $\mathrm{PC}$ will be done by the surveillance cognizant engineer, and will need to be done only once.

6.7.4.6 At each of the two SY-101 MITs, perform an MIT gamma probe scan and then an MIT neutron probe scan (with neutron source installed).

6.7.4.7 After the van has completed these scans, return to the 272WA garage.

6.7.4.8 Plug in modem line to computer data pigtail and download data (F6 function key on computer keyboard). 
HNF-3838 Rev. 1

7.0 TEST DATA SHEETS 


\begin{tabular}{|c|c|c|c|c|}
\hline \multicolumn{5}{|c|}{ 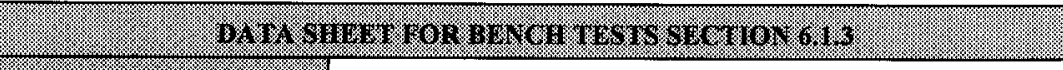 } \\
\hline \multicolumn{2}{|c|}{ 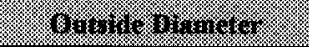 } & \multicolumn{3}{|l|}{ Signed/Date } \\
\hline Probe & Position & $\begin{array}{l}\text { Rotation: } 0 \\
\text { (inches) }\end{array}$ & $\begin{array}{l}\text { Rotation: } 90 \\
\text { (inches) }\end{array}$ & $\begin{array}{r}\text { Average } \\
\text { (inches) }\end{array}$ \\
\hline \multirow[t]{3}{*}{ MIT Neutron } & Top & & & \\
\hline & Middle & & & \\
\hline & Bottom & & & \\
\hline \multirow[t]{3}{*}{ MIT Gamma } & Top & & & \\
\hline & Middle & & & \\
\hline & Bottom & & & \\
\hline \multicolumn{2}{|c|}{$8 \sin 3$} & \multicolumn{3}{|l|}{ Signed/Date } \\
\hline Probe & \multicolumn{2}{|c|}{ Length (inches) } & & \\
\hline \multicolumn{5}{|l|}{ MIT Neutron } \\
\hline \multicolumn{5}{|l|}{ MIT Gamma } \\
\hline \multicolumn{2}{|c|}{$\sqrt{3} \cdot 3.18$} & \multicolumn{3}{|l|}{ Signed/Date } \\
\hline Probe & \multicolumn{2}{|c|}{ Weight (lbs) } & \multicolumn{2}{|c|}{ Comments } \\
\hline MIT Neutron & & & \multicolumn{2}{|c|}{$\begin{array}{l}\text { Measured weight includes probe, ballast, and } \\
\text { dummy source holder }\end{array}$} \\
\hline MIT Gamma & & & \multicolumn{2}{|c|}{ Measured weight includes probe and ballast } \\
\hline \multicolumn{5}{|c|}{ 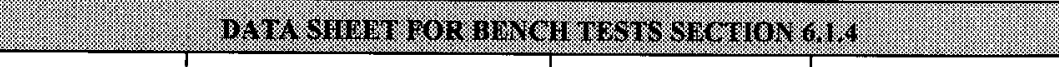 } \\
\hline Probe & \multicolumn{2}{|c|}{ Measured Current (ma) } & $\begin{array}{c}\text { Pulse Shape } \\
\text { Verified }\end{array}$ & Date \\
\hline MIT Neutron & & & Signed: & Date: \\
\hline MIT Gamma & & & Signed: & Date: \\
\hline
\end{tabular}




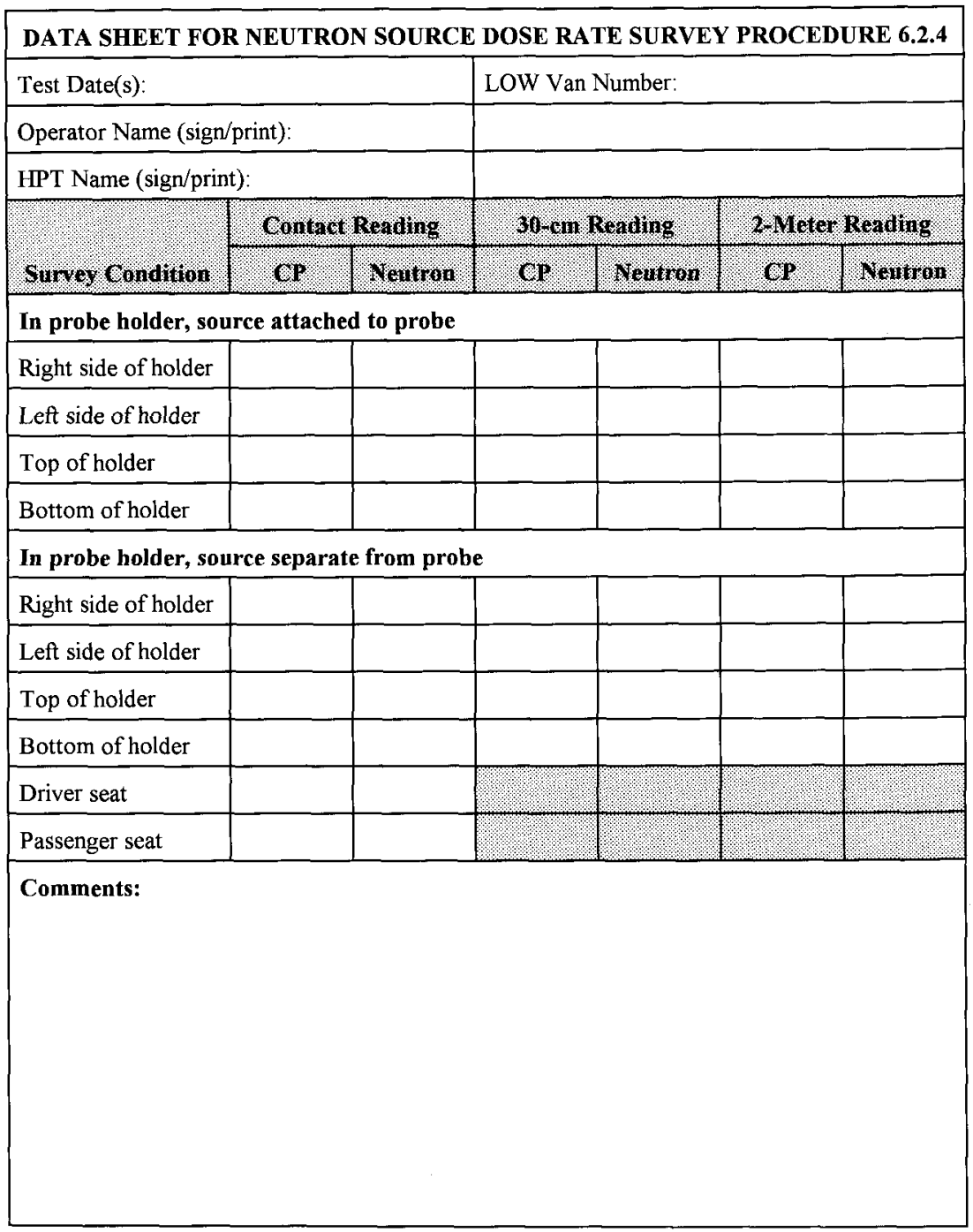


HNF-3838 Rev. 1

\begin{tabular}{|c|c|c|c|c|}
\hline \multicolumn{5}{|c|}{ DATA SHEET FOR DEPTH/WEIGHT TEST PROCEDURE 6.3.4 } \\
\hline \multicolumn{2}{|c|}{$\begin{array}{l}\text { Test Date: } \\
\text { LOW Van No. }\end{array}$} & \multicolumn{3}{|c|}{ Signed/Date } \\
\hline 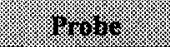 & 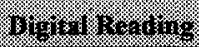 & (1) & 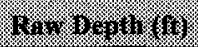 & 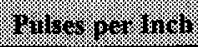 \\
\hline \multirow[t]{3}{*}{ MIT Gamma } & & 1 & & \\
\hline & & 2 & & \\
\hline & & 3 & & \\
\hline \multirow[t]{3}{*}{ MIT Neutron } & & 1 & & \\
\hline & & 2 & & . \\
\hline & & 3 & & \\
\hline
\end{tabular}




\begin{tabular}{|c|c|c|c|c|c|c|}
\hline \multicolumn{7}{|c|}{ DATA SHEET FOR NEUTRON PROBE COUNT-RATE TEST PROCEDURE 6.4.4 } \\
\hline \multicolumn{3}{|l|}{ Test Date(s): } & & & & \\
\hline \multicolumn{7}{|c|}{ Operator Name (sign/print): } \\
\hline \multicolumn{3}{|c|}{ Operator Name (sign/print): } & & & & \\
\hline & t & \multicolumn{5}{|c|}{ Inithi and ditc each box as cach trial is completed. } \\
\hline rest & No. & Trial & Tralla & 171913 & Irinl 4 & Trial 5 \\
\hline $\begin{array}{l}\text { 272WA Garage } \\
\text { Calibration Fixture }\end{array}$ & & & & & & \\
\hline
\end{tabular}

\begin{tabular}{|c|c|c|c|c|c|c|}
\hline \multicolumn{7}{|c|}{ DATA SHEET FOR GAMMA PROBE COUNT-RATE TEST PROCEDURE 6.4.5 } \\
\hline \multicolumn{3}{|l|}{ Test Date(s): } & & & & \\
\hline \multicolumn{7}{|c|}{ Operator Name (sign/print): } \\
\hline \multicolumn{3}{|c|}{ Operator Name (sign/print): } & & & & \\
\hline \multirow[b]{2}{*}{ Test } & \multirow{2}{*}{ Van } & Initi & di datere & box as en & Malis is e & eted. \\
\hline & & Iriali: & Inal2 & Trial 3 & Iratil & rinals \\
\hline $\begin{array}{l}\text { 272WA Garage } \\
\text { Calibration Fixture }\end{array}$ & & & & & & \\
\hline
\end{tabular}


HNF-3838 Rev. 1

DATA SHEET FOR BARREL TEST PROCEDURES 6.5.4 - 6.5.6

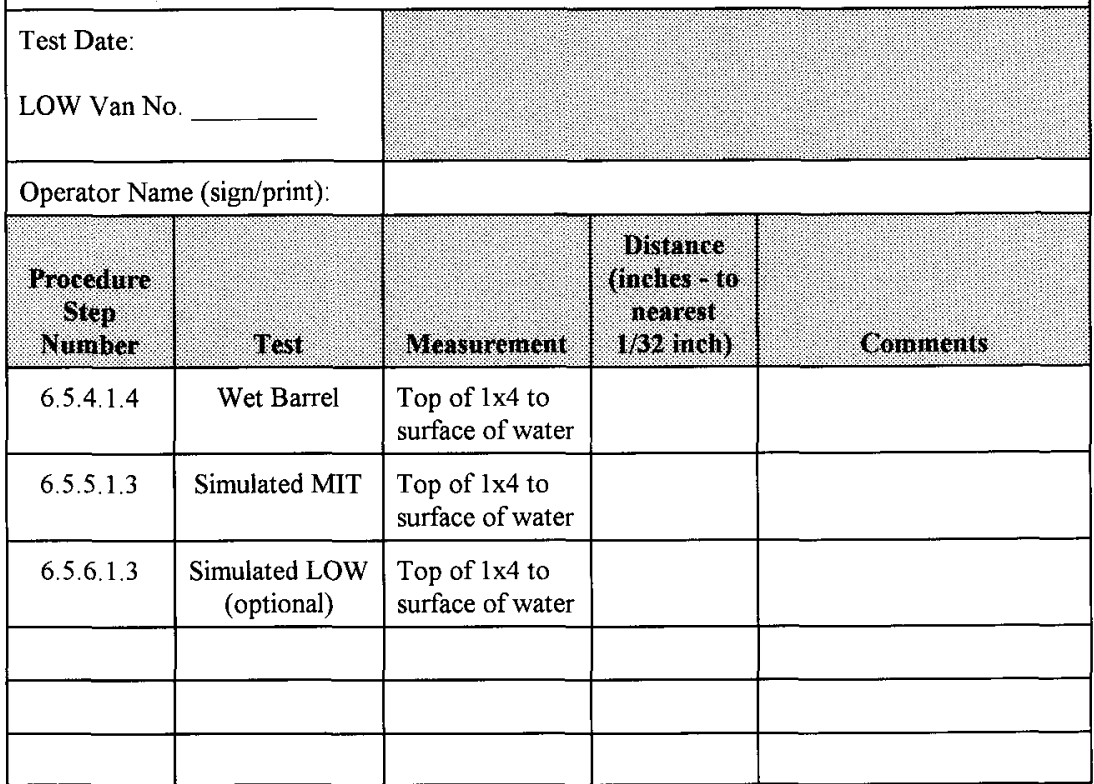


HNF-3838 Rev. 1

8.0 EXCEPTIONS TO OPERATIONS / ACCEPTANCE TEST SECTION 


\subsection{TEST EXECUTION APPROVAL SHEET}

The undersigned certify that all required tests have been completed and that all requirements were either met or an exception was duly noted. If an exception was noted, the appropriate resolution of that exception has also been specified.

\begin{tabular}{lcc}
\hline Test Engineer (sign) & (print) & Date \\
& & \\
\hline Cognizant Engineer (sign) & (print) & Date
\end{tabular}

\begin{tabular}{lll}
\hline Operations Representative (sign) & (print) Date
\end{tabular}

\begin{tabular}{lll}
\hline Quality Assurance Representative (sign) & (print) Date
\end{tabular}




\section{DISTRIBUTION SHEET}

\begin{tabular}{|c|c|c|c|c|c|}
\hline \multirow{2}{*}{$\begin{array}{l}\text { To } \\
\text { Distribution }\end{array}$} & \multirow{2}{*}{\multicolumn{3}{|c|}{$\begin{array}{l}\text { From } \\
\text { Electrical I \& C }\end{array}$}} & \multicolumn{2}{|l|}{ Page 1 of 1} \\
\hline & & & & \multicolumn{2}{|c|}{ Date March 2, 1999} \\
\hline \multicolumn{4}{|l|}{ Project Title/Work Order } & \multicolumn{2}{|c|}{ EDT No. 140125} \\
\hline \multicolumn{4}{|c|}{$\begin{array}{l}\text { Acceptance and Operational Test Procedure for Neutron and Gamma } \\
\text { Probe Application to Tank } 241-S Y-101 \text { MITs }\end{array}$} & \multicolumn{2}{|c|}{ ECN No. 651841} \\
\hline Name & MSIN & $\begin{array}{c}\text { Text } \\
\text { With All } \\
\text { Attach. }\end{array}$ & Text Only & $\begin{array}{l}\text { Attach./ } \\
\text { Appendix } \\
\text { Only }\end{array}$ & $\begin{array}{l}\text { EDT/ECN } \\
\text { Only }\end{array}$ \\
\hline $\begin{array}{l}\text { J. D. Adrian } \\
\text { D. A. Barnes } \\
\text { R. E. Bauer } \\
\text { N. S. Cannon (3) } \\
\text { J. D. Criddle, Jr. } \\
\text { P. R. Deichelbohrer } \\
\text { J. G. Douglas } \\
\text { G. D. Johnson } \\
\text { N. W. Kirch } \\
\text { P. F. Kison } \\
\text { L. S. Krogsrud } \\
\text { D. C. Larsen } \\
\text { M. D. Rickenbach } \\
\text { D. Scott, Jr. } \\
\text { D. L. Sparks } \\
\text { F. S. Stong } \\
\text { R. R. True } \\
\text { R. P. Tucker } \\
\text { Central Files (1) + Orig. }\end{array}$ & $\begin{array}{l}\text { T4-01 } \\
\text { R2-11 } \\
\text { S7-73 } \\
\text { L6-38 } \\
\text { S7-12 } \\
\text { S7-12 } \\
\text { H3-26 } \\
\text { S7-73 } \\
\text { R2-11 } \\
\text { R3-73 } \\
\text { T4-07 } \\
\text { T4-08 } \\
\text { H3-28 } \\
\text { S5-07 } \\
\text { S5-03 } \\
\text { H3-27 } \\
\text { T4-07 } \\
\text { T4-07 } \\
\text { A3-88 }\end{array}$ & 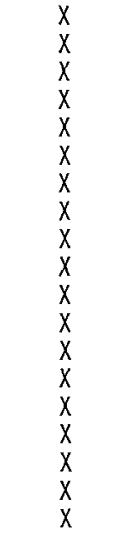 & & & \\
\hline
\end{tabular}

